\title{
INFLUENCE OF FOLIAR APPLICATION OF Fe, Zn, Mo AND LITHOVIT ON GROWTH AND PRODUCTIVITY OF STEVIA PLANT (Stevia rebaudiana, Bert.)
}

\author{
Amany M.I. Soliman, A.E. Awad, A.S. Gendy and M.A. Abdelkader" \\ Hort. Dept., Fac. Agric., Zagazig Univ., Egypt
}

Received: 16/09/2018 ; Accepted: 21/10/2018

\begin{abstract}
This experiment was carried out to study the effect of foliar spraying of some micronutrients $(\mathrm{Fe}+\mathrm{Zn}+\mathrm{Mo}$ at $0+0+0,0.25+0.15+1.5$ and $0.50+0.30+3 \mathrm{~g} / 1$, respectively), lithovit (foliar fertilizer enhance plant photosynthesis by releasing $\mathrm{CO}_{2}$ in leaf stomata, at $0,2,4$ and $6 \mathrm{~g} / \mathrm{l}$ ) and their interactions on growth and productivity of stevia plant. The experiment was performed as a splitplot in complete randomized block design with three replicates during 2015 and 2016 seasons in the Expt. Farm, Dept. Botany, Fac. Sci., Benha Univ., Egypt. The obtained results cleared that micronutrients of $\mathrm{Fe}+\mathrm{Zn}+\mathrm{Mo}$ at $0.50+0.30+3 \mathrm{~g} / \mathrm{l}$, respectively increased growth parameters (plant height, number of branches and leaves/plant and dry weight of leaves/plant), yield components (total dry leaves and herb yield/faddan), chemical constituents (reducing and non reducing sugars and total chlorophyll content in leaves) and active ingredients (stevioside and rebaudioside glycosides in leaves). Moreover, the highest values of these parameters were registered by foliar spray of lithovit at 4 or $6 \mathrm{~g} / 1$ without significant differences between them in the $2^{\text {nd }}$ cut. Two compounds of glycosides of Stevia rebaudiana plant were identified by high performance liquid chromatography (HPLC). The main component was stevioside which followed by rebaudioside. Generally, spraying Stevia rebaudiana plant three times per season with lithovit at $4 \mathrm{~g} / 1$ plus $\mathrm{Fe}+\mathrm{Zn}+$ Mo at $0.50,0.30,3 \mathrm{~g} / 1$, respectively enhance plant growth, yield and chemical constituents as well as active ingredients.
\end{abstract}

Key words: Stevia, Fe, Zn, Mo, lithovit, growth, yield, stevioside, rebaudioside.

\section{INTRODUCTION}

Stevia (Stevia rebaudiana, Bertoni) belongs to the family Asteraceae and is one of the most important low-calorie natural sweetener plants. The glycosides extracted from stevia leaf, as allnatural low-calorie sweeteners, are nontoxic and nonmutagenic compounds (Lyakhovkin et al., 1993). The leaf extract of stevia has documented antibacterial, antifungal (including anti-yeast), anti-inflammatory, antimicrobial, antiviral, cardiotonic, diuretic, and hypoglycemic properties. It is a boon for those suffering from diabetes (Curi et al., 1986).

Foliar feeding is a relatively new and controversial technique of feeding plants by applying liquid fertilizer directly to their leaves (Bernal et al., 2007; Baloch et al., 2008).
Microelements as iron $(\mathrm{Fe})$, zinc $(\mathrm{Zn})$ and molybdenum (Mo) usually added to foliar fertilizers in order to compensate their deficiency especially in arid and semi arid regions (Kaya $\boldsymbol{e t}$ al., 2005). Micronutrients, especially $\mathrm{Fe}$ and $\mathrm{Zn}$, act either as metal components of various enzymes or as functional, structural, or regulatory cofactors. Thus, they are associated with saccharide metabolism, photosynthesis and protein synthesis (Marschner, 1995). Molybdenum is an important micronutrient for plant growth and occurs in several enzymes (nitrate reductase, nitrogenase, xanthine dehydrogenase and aldehyde oxidase) catalyzing diverse oxidation-reduction reactions in plants (Mengel and Kirkby, 2001). In addition, molybdenum involved in nitrate assimilation, nitrogen fixation processes as well as transport of nitrogen compounds in plants and it plays a crucial role in nitrogen metabolism in plant tissues (Li et al., 2013).

* Corresponding author: Tel. : +201008002904

E-mail address: mohammedahmed1980@yahoo.com 
Recently, Nano-fertilizers are used as an alternative to conventional fertilizers due to slow release and efficient use by plants. Lithovit compound particles contain calcium carbonate $(80 \%)$, magnesium carbonate $(4.6 \%)$ and $\mathrm{Fe}$ $(0.75 \%)$. The beneficial effect of this compound is being contains calcium carbonate $\left(\mathrm{CaCO}_{3}\right)$ decomposes to calcium oxide $(\mathrm{CaO})$ and carbon dioxide $\left(\mathrm{CO}_{2}\right)$ in leaves stomata, and this $\mathrm{CO}_{2}$ increases photosynthesis process leading to increases in carbon uptake and assimilation, thereby increasing plant growth (Carmen et al., 2014).

However, the present investigation was carried out to examine the effects of foliar spraying of some micronutrients $(\mathrm{Fe}+\mathrm{Zn}+\mathrm{Mo})$ and lithovit fertilizer on growth characteristics and yield components as well as some chemical constituents of Stevia rebaudiana.

\section{MATERIALS AND METHODS}

This study was conducted during the two consecutive seasons of 2015 and 2016 at the Expt. Farm, Botany Dept., Fac. Sci., Benha Univ. Egypt. This work was carried out to examine effects of foliar spray of some micronutrients $(\mathrm{Fe}+\mathrm{Zn}+\mathrm{Mo})$ at three levels, lithovit foliar at four levels and their interactions on growth, yield and some chemical constituents of stevia plant.

Stevia seedlings were obtained from tissue culture glass house of Sugar Crops Res. Inst., Agric. Res. Center, Ministry of Agriculture, Egypt. On $10^{\text {th }}$ and $18^{\text {th }}$ April during the $1^{\text {st }}$ and $2^{\text {nd }}$ seasons, respectively, seedlings were transplanted in the experimental plots. The experimental plot area was $2.5 \times 1.8 \mathrm{~m}$ containing three rows, with $60 \mathrm{~cm}$ between them. The distance between plants in row was $50 \mathrm{~cm}$, so each plot contains 15 plants, under drip irrigation system. The mechanical and chemical properties of the used soil are shown in Table 1 according to Chapman and Pratt (1978).

\section{Micronutrients Levels}

Three levels of iron $(\mathrm{Fe})+$ zinc $(\mathrm{Zn})+$ molybdenum (Mo) were tested in this study. Iron source was ferrous sulfate $\left(\mathrm{FeSO}_{4}\right)$. It was sprayed three times during season at concentrations of 0.0 ,
0.25 and $0.50 \mathrm{~g} / 1$ at 40,55 and 70 days from transplanting. Molybdenum was used as ammonium molybdate $\left[\left(\mathrm{NH}_{4}\right) 6 \mathrm{Mo}_{7} \mathrm{O}_{24} \cdot 4 \mathrm{H}_{2} \mathrm{O}\right]$ at concentrations of $0.0,1.5$ and $3.0 \mathrm{~g} / 1$. While, zinc source was as zinc sulfate $\left(\mathrm{ZnSO}_{4}\right)$. It was tested at $0.0,0.15$ and $0.30 \mathrm{~g} / \mathrm{l}$. Each of Mo and $\mathrm{Zn}$ was sprayed three times during season; $i$. e., after 30 , 45 and 60 days from transplanting. Therefore, the three tested micronutrients levels were as follows:

Micro.1: Plants were without micronutrients spray for control,

Micro.2: Plants were sprayed with $0.25 \mathrm{~g} / 1$ $\mathrm{Fe}+0.15 \mathrm{~g} / 1 \mathrm{Zn}+1.5 \mathrm{~g} / 1 \mathrm{Mo}$ and

Micro.3: Plants were sprayed with $0.50 \mathrm{~g} / 1$ $\mathrm{Fe}+0.30 \mathrm{~g} / 1 \mathrm{Zn}+3.0 \mathrm{~g} / \mathrm{l} \mathrm{Mo}$

\section{Lithovit Levels}

Four lithovit levels $(0,2,4$ and $6 \mathrm{~g} / \mathrm{l})$ were foliar sprayed three times at 35, 50 and 65 days from transplanting. The German foliar fertilizer lithovit was used in this study. It is $100 \%$ organic calcium carbonate from natural limestone deposits. It was contained $75.0 \% \mathrm{CaCO}_{3}, 5.0 \%$ $\mathrm{MgCO}_{3}, 0.25 \% \mathrm{Fe}$ and $0.02 \% \mathrm{Mn}$. The lithovit was obtained from Agrolink company as a powder.

The Experimental layout was factorial experiment $(3 \times 4)$ in a split-plot design between the above mentioned three micronutrients levels as main plots and the four lithovit levels as subplots in randomized complete blocks design with three replicates. So, the experiment included 12 interaction treatments.

All experimental plots were subjected to N,P and $\mathrm{K}$ fertilization at $150,200,100 \mathrm{~kg} / \mathrm{fad}$., of ammonium sulphate $(20.5 \% \mathrm{~N})$, calcium super phosphate $\left(15.5 \mathrm{P}_{2} \mathrm{O}_{5}\right)$ and potassium sulphate

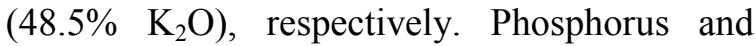
potassium fertilizers were added during soil preparation. While, nitrogen fertilizer was applied in two equal portions (after 30 and 60 days from transplanting). In addition, all plants were received the recommended normal agricultural practices for stevia plant whenever needed.

\section{Data Recorded}

Plants were subjected to two cuts. The first cut was after 3 months from transplanting; i.e., on $10^{\text {th }}$ and $18^{\text {th }}$ July for $1^{\text {st }}$ and $2^{\text {nd }}$ seasons, 
Table 1. Physical and chemical properties of experimental farm soil (average of two seasons)

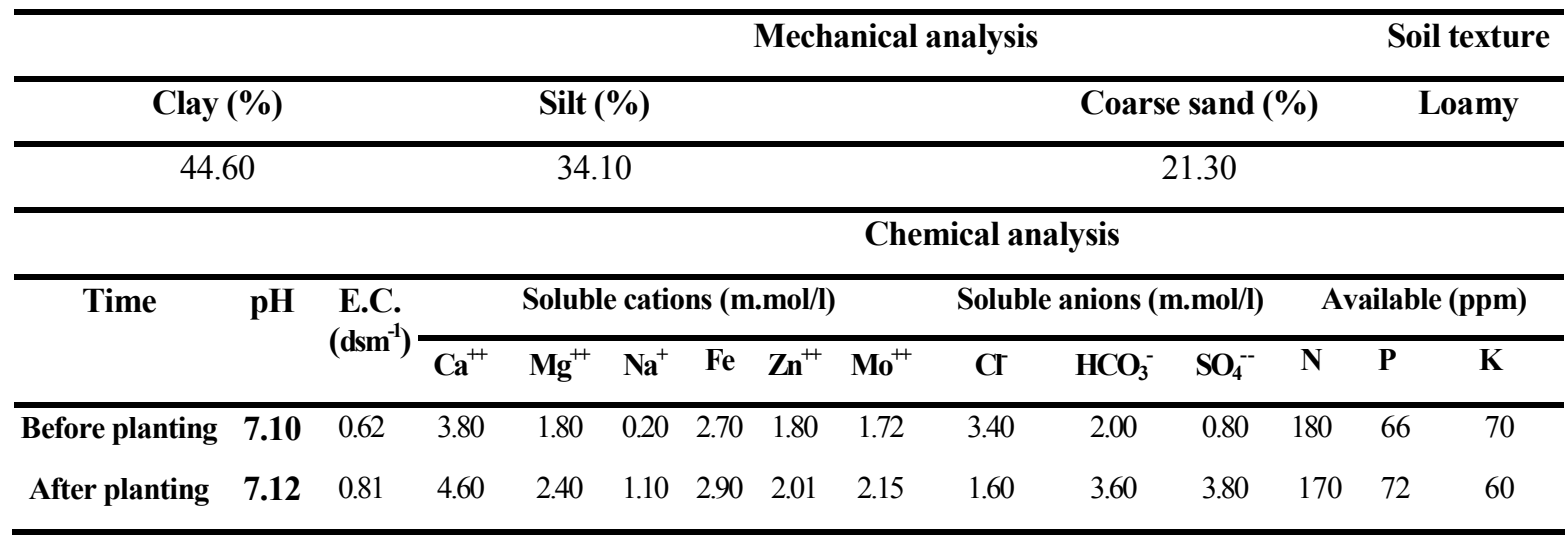

respectively. While, the second cut was 3 months after the $1^{\text {st }}$ cut; i.e., on $10^{\text {th }}$ and $18^{\text {th }}$ October for $1^{\text {st }}$ and $2^{\text {nd }}$ seasons, respectively. Harvesting was done by cutting the aerial parts $10 \mathrm{~cm}$ above the soil surface of plants. The following data were recorded for each cut in the two experimental seasons:

\section{Growth parameters}

Plant height $(\mathrm{cm})$, number of both branches and leaves per stevia plant and leaves dry weight/plant $(\mathrm{g})$ were recorded. Three plants were randomly chosen from each experimental plot for growth parameter determinations.

\section{Yield components}

Plants of the central row of each experimental plot were used for yield component determinations. Yield component included dry leaves/fad. (kg) and dry herb yield/fad. (kg). They were calculated mathematically from the recorded data of dry leaves/plant (g) and dry herb/ plant (g).

\section{Chemical constituents and active ingredients}

Reducing sugars, non reducing sugars is dry leaves and total chlorophyll content $\mathrm{a}+\mathrm{b}(\mathrm{mg} / \mathrm{g})$ in green leaves were determined in stevia leaves according to Mazumder and Majumder (2003).

\section{Determination of stevioside and rebaudioside}

Two compounds of glycosides (stevioside and rebaudioside) of Stevia rebaudiana plant were identified by HPLC as described by Aranda-González et al. (2015).

\section{Statistical Analysis}

The obtained data was statistically analyzed and the means were compared using least significant difference (LSD) at 5\% level; computer program Statistix Version 9 was used (Analytical Software, 2008).

\section{RESULTS AND DISCUSSION}

\section{Growth Parameters}

\section{Effect of micronutrients}

The results presented in Table 2 show that stevia plant height $(\mathrm{cm})$, branch and leaf numbers per plant and leaves dry weight per plant $(\mathrm{g})$ significantly increased with most of micronutrients levels compared to control. Furthermore, micronutrients level at $0.50+0.30$ $+3.00 \mathrm{~g} / \mathrm{l}$ of $\mathrm{Fe}+\mathrm{Zn}+\mathrm{Mo}$ recorded higher increases in stevia growth parameters compared with the other treatments under study, in most cases, in the two cuts during the two seasons. These results might be due to the essential role of micronutrients of $\mathrm{Fe}, \mathrm{Zn}$ and Mo for growth and development of living plants. As they are found in the most reactions and are fundamental for cellular processes and in proteins and enzymes for structural and catalytic enzyme activities leading to taller, more branches and leaves and heaviest leaves per plant (Hall and Williams, 2003). These results are in line with those stated by Zehtab-Salmasi et al. (2008) on peppermint, Said-Al Ahl and Mahmoud (2010) on basil plant and Ziedan and Eisa (2016) on dill plant. 
Table 2. Effect of foliar spray with micronutrients on growth parameters of Stevia rebaudiana plant during 2015 and 2016 seasons

\begin{tabular}{|c|c|c|c|c|c|c|c|c|}
\hline \multirow{2}{*}{$\begin{array}{c}\text { Micronutrients } \\
\text { level }(\mathrm{g} / \mathrm{l}) \\
(\mathrm{Fe}+\mathrm{Zn}+\mathrm{Mo})\end{array}$} & \multicolumn{2}{|c|}{$\begin{array}{c}\text { Plant height } \\
\text { (cm) }\end{array}$} & \multicolumn{2}{|c|}{$\begin{array}{c}\text { Number of } \\
\text { branches/plant }\end{array}$} & \multicolumn{2}{|c|}{$\begin{array}{l}\text { Number of } \\
\text { leaves/plant }\end{array}$} & \multicolumn{2}{|c|}{$\begin{array}{c}\text { Leaves dry } \\
\text { weight/plant (g) }\end{array}$} \\
\hline & $1^{\text {st }}$ cut & $2^{\text {nd }}$ cut & $1^{\text {st }}$ cut & $2^{\text {nd }}$ cut & $1^{\text {st }}$ cut & $2^{\text {nd }}$ cut & $1^{\text {st }}$ cut & $2^{\text {nd }}$ cut \\
\hline & \multicolumn{8}{|c|}{2015 season } \\
\hline Control & 23.52 & 57.75 & 12.08 & 20.67 & 53.75 & 106.67 & 2.31 & 3.91 \\
\hline $0.25+0.15+1.50$ & 28.06 & 64.83 & 14.84 & 22.94 & 73.75 & 119.42 & 2.82 & 4.43 \\
\hline $0.50+0.30+3.00$ & 32.97 & 77.50 & 16.08 & 25.92 & 82.34 & 125.67 & 3.28 & 5.18 \\
\hline \multirow[t]{2}{*}{ LSD at $5 \%$} & 6.38 & 18.84 & 1.48 & NS & 10.36 & NS & 0.27 & 0.79 \\
\hline & \multicolumn{8}{|c|}{2016 season } \\
\hline Control & 34.80 & 72.59 & 21.75 & 11.25 & 188.17 & 208.42 & 2.36 & 3.68 \\
\hline $0.25+0.15+1.50$ & 41.25 & 89.50 & 25.84 & 15.50 & 216.91 & 272.58 & 3.26 & 6.46 \\
\hline $0.50+0.30+3.00$ & 46.67 & 94.00 & 31.50 & 18.25 & 236.50 & 390.83 & 5.10 & 12.37 \\
\hline LSD at $5 \%$ & NS & 12.33 & NS & 3.96 & 47.99 & 67.97 & NS & 1.92 \\
\hline
\end{tabular}

\section{Effect of lithovit}

Results tabulated in Table 3 show that plant height, number of branches and leaves per plant as well as leaves dry weight per plant were gradually increased with increasing lithovit rates in the two cuts in both seasons, in most cases. However, in the $2^{\text {nd }}$ season in both cuts, the different rates of lithovit did not gave significant increase compared to control in most growth parameters of stevia plants. In addition, the highest rate of lithovit gave highest values in this regard without significant differences between other ones under study, in most cases. It is well known that the tested micronutrients ( $\mathrm{Fe}, \mathrm{Zn}$ and $\mathrm{Mo}$ ) supply the plant with the required necessary for the growth and development. Besides, nanoparticles (lithovit) improved the plant growth parameters (Esitken and Turan, 2004; Carbonell et al., 2011). In addition, Ghatas and Mohamed (2018) found that lithovit at $1 \mathrm{~g} / 1$ resulted in the heaviest fresh and dry weights of lemongrass herb/plant ( $\mathrm{g}$ ) and the highest number of tiller/plant.

\section{Effect of Interaction Between Micronutrients and Lithovit}

Tables 4 and 5 illustrates that, generally, interaction between micronutrients levels and lithovit rates significantly increased plant height, branch and leaf number/plant and leaves dry weight/plant compared to the control in the two seasons in both cuts. Furthermore, the best interaction treatment in this regard was that of $\mathrm{Fe}+\mathrm{Zn}+\mathrm{Mo}$ at $0.50+0.30+3.00 \mathrm{~g} / 1$ interacted with lithovit at $6 \mathrm{~g} / 1$. Also, all interaction treatments were higher than individual micronutrients levels or individual lithovit rates. These results are in harmony with those reported by Ghatas and Mohamed (2018) on Cymbopogon citruts plant.

Moreover, as mentioned above, both micronutrients levels and lithovit rates (each alone) increased growth parameters of stevia plant, in turn; they together might maximize their effects leading to taller, more branches and leaves and heaviest leaves.

\section{Yield Components}

\section{Effect of micronutrients}

There were significant differences, in most cases, in dry leaves and dry herb per faddan $(\mathrm{kg})$ under the effect of all the tested micronutrients levels (Table 6). Furthermore, these yield component parameters were increased gradually by increasing the used micronutrients level. The highest level of micronutrients $(\mathrm{Fe}+\mathrm{Zn}+\mathrm{Mo}$ at $0.50+0.30+3.00 \mathrm{~g} / \mathrm{l})$ ) gave significant increases 
Table 3. Effect of foliar spray of lithovit on growth parameters of Stevia rebaudiana plant during 2015 and 2016 seasons

\begin{tabular}{|c|c|c|c|c|c|c|c|c|}
\hline \multirow[t]{2}{*}{$\begin{array}{c}\text { Lithovit rate } \\
(\mathrm{g} / \mathrm{l})\end{array}$} & \multicolumn{2}{|c|}{$\begin{array}{l}\text { Plant height } \\
\text { (cm) }\end{array}$} & \multicolumn{2}{|c|}{$\begin{array}{c}\text { Number of } \\
\text { branches/plant }\end{array}$} & \multicolumn{2}{|c|}{$\begin{array}{l}\text { Number of } \\
\text { leaves/plant }\end{array}$} & \multicolumn{2}{|c|}{$\begin{array}{c}\text { Leaves dry } \\
\text { weight/plant (g) }\end{array}$} \\
\hline & $1^{\text {st }}$ cut & $2^{\text {nd }}$ cut & $1^{\text {st }}$ cut & $2^{\text {nd }}$ cut & $1^{\text {st }}$ cut & $\overline{2^{\text {nd }} \text { cut }}$ & $1^{\text {st }}$ cut & $\overline{2^{\text {nd }} \text { cut }}$ \\
\hline & \multicolumn{8}{|c|}{2015 season } \\
\hline Control & 25.03 & 60.22 & 13.00 & 21.78 & 60.33 & 110.00 & 2.58 & 4.36 \\
\hline 2 & 27.62 & 62.44 & 13.78 & 22.44 & 69.56 & 117.78 & 2.68 & 4.42 \\
\hline 4 & 28.88 & 67.33 & 14.89 & 26.26 & 74.22 & 119.55 & 2.95 & 4.58 \\
\hline 6 & 31.20 & 76.78 & 15.67 & 22.22 & 75.67 & 121.67 & 3.00 & 4.66 \\
\hline \multirow[t]{2}{*}{ LSD at $5 \%$} & 5.90 & 13.91 & 1.55 & NS & 8.43 & NS & 0.38 & NS \\
\hline & \multicolumn{8}{|c|}{2016 season } \\
\hline Control & 37.89 & 79.22 & 23.33 & 12.78 & 198.55 & 238.66 & 2.96 & 6.63 \\
\hline 2 & 40.67 & 83.67 & 25.11 & 14.89 & 211.66 & 278.89 & 3.44 & 7.41 \\
\hline 4 & 42.00 & 88.11 & 27.00 & 16.00 & 218.88 & 293.33 & 3.60 & 7.80 \\
\hline 6 & 43.07 & 90.45 & 30.00 & 16.33 & 225.66 & 315.55 & 4.29 & 8.16 \\
\hline LSD at $5 \%$ & NS & 8.77 & NS & NS & NS & 56.41 & NS & NS \\
\hline
\end{tabular}

Table 4. Effect of the interaction between micronutrients and lithovit on plant height and branch number/ plant of Stevia rebaudiana during 2015 and 2016 seasons

\begin{tabular}{lcrrrrrrr}
\hline $\begin{array}{c}\text { Micronutrient } \\
\text { level (g/l) }\end{array}$ & \multicolumn{7}{c}{ Lithovit rate (g/l) } \\
\cline { 2 - 8 } (Fe+Zn+Mo)
\end{tabular}


Table 5. Effect of the interaction between micronutrients and lithovit on leave's number/ plant and leave's dry weight/plant of Stevia rebaudiana during 2015 and 2016 seasons

\begin{tabular}{|c|c|c|c|c|c|c|c|c|}
\hline \multirow{3}{*}{$\begin{array}{c}\text { Micronutrient } \\
\text { level (g/l) } \\
\text { (Fe: Zn: Mo) }\end{array}$} & \multicolumn{8}{|c|}{ Lithovit rate (g/l) } \\
\hline & Control & 2 & 4 & 6 & Control & 2 & 4 & 6 \\
\hline & \multicolumn{4}{|c|}{ First cut } & \multicolumn{4}{|c|}{ Second cut } \\
\hline & \multicolumn{8}{|c|}{ Number of leaves/plant } \\
\hline & \multicolumn{8}{|c|}{2015 season } \\
\hline Control & 33.33 & 57.00 & 62.33 & 62.33 & 91.67 & 110.33 & 112.33 & 112.33 \\
\hline $0.25+0.15+1.50$ & 69.00 & 71.67 & 77.33 & 77.00 & 115.00 & 118.67 & 121.33 & 122.67 \\
\hline $0.50+0.30+3.00$ & 78.67 & 80.00 & 83.00 & 87.67 & 123.33 & 124.33 & 125.00 & 130.00 \\
\hline \multirow[t]{2}{*}{ LSD at $5 \%$} & \multicolumn{4}{|c|}{16.20} & \multicolumn{4}{|c|}{36.87} \\
\hline & \multicolumn{8}{|c|}{2016 season } \\
\hline Control & 156.00 & 192.00 & 201.66 & 203.00 & 164.00 & 210.33 & 228.00 & 231.33 \\
\hline $0.25+0.15+1.50$ & 205.66 & 207.66 & 218.33 & 234.00 & 233.33 & 262.67 & 283.67 & 310.67 \\
\hline $0.50+0.30+3.00$ & 234.00 & 235.33 & 236.66 & 240.00 & 318.66 & 363.66 & 368.33 & 512.66 \\
\hline \multirow[t]{3}{*}{ LSD at $5 \%$} & \multicolumn{4}{|c|}{92.65} & \multicolumn{4}{|c|}{107.61} \\
\hline & \multicolumn{8}{|c|}{ Leave's dry weight/plant (g) } \\
\hline & \multicolumn{8}{|c|}{2015 season } \\
\hline Control & 1.90 & 2.07 & 2.59 & 2.68 & 3.77 & 3.83 & 3.97 & 4.06 \\
\hline $0.25+0.15+1.50$ & 2.71 & 2.73 & 2.91 & 2.93 & 4.27 & 4.33 & 4.50 & 4.60 \\
\hline $0.50+0.30+3.00$ & 3.12 & 3.23 & 3.36 & 3.39 & 5.03 & 5.10 & 5.27 & 5.33 \\
\hline \multirow[t]{2}{*}{ LSD at $5 \%$} & \multicolumn{4}{|c|}{0.63} & \multicolumn{4}{|c|}{0.98} \\
\hline & \multicolumn{8}{|c|}{2016 season } \\
\hline Control & 2.03 & 2.23 & 2.32 & 2.85 & 1.70 & 3.80 & 4.33 & 4.87 \\
\hline $0.25+0.15+1.50$ & 3.02 & 3.17 & 3.37 & 3.48 & 6.23 & 6.27 & 6.40 & 6.93 \\
\hline $0.50+0.30+3.00$ & 3.83 & 4.92 & 5.12 & 6.53 & 11.97 & 12.17 & 12.67 & 12.67 \\
\hline LSD at $5 \%$ & \multicolumn{4}{|c|}{5.35} & \multicolumn{4}{|c|}{5.05} \\
\hline
\end{tabular}

Table 6. Effect of foliar spray with micronutrients on yield components and some chemical constituents of Stevia rebaudiana plant during 2015 and 2016 seasons

\begin{tabular}{|c|c|c|c|c|c|c|c|c|c|c|}
\hline \multirow{3}{*}{$\begin{array}{c}\text { Micronutrient } \\
\text { level (g/l) } \\
\text { (Fe: Zn: Mo) }\end{array}$} & \multicolumn{4}{|c|}{ Yield components } & \multicolumn{6}{|c|}{ Chemical constituents } \\
\hline & \multicolumn{2}{|c|}{$\begin{array}{c}\text { Dry leaves } \\
\text { yield/fad. }(\mathrm{kg})\end{array}$} & \multicolumn{2}{|c|}{$\begin{array}{c}\text { Dry herb } \\
\text { yield/fad. (kg) }\end{array}$} & \multicolumn{2}{|c|}{$\begin{array}{l}\text { Reducing } \\
\text { sugar }(\%)\end{array}$} & \multicolumn{2}{|c|}{$\begin{array}{l}\text { Non-reducing } \\
\text { sugar }(\%)\end{array}$} & \multicolumn{2}{|c|}{$\begin{array}{c}\text { Total chlorophyl } \\
\text { content (mg/g) }\end{array}$} \\
\hline & $1^{\text {st }}$ cut & $2^{\text {nd }}$ cut & $1^{\text {st }}$ cut & $2^{\text {nd }}$ cut & $1^{\text {st }}$ cut & $2^{\text {nd }}$ cut & $1^{\text {st }}$ cut & $2^{\text {nd }}$ cut & $1^{\text {st }}$ cut & $2^{\text {nd }}$ cut \\
\hline & \multicolumn{10}{|c|}{2015 season } \\
\hline Control & 30.78 & 52.11 & 82.69 & 139.45 & 0.90 & 0.98 & 3.78 & 2.88 & 2.29 & 1.50 \\
\hline $0.25+0.15+1.50$ & 37.65 & 59.00 & 111.25 & 170.79 & 1.30 & 1.87 & 5.06 & 4.38 & 2.88 & 1.72 \\
\hline $0.50+0.30+3.00$ & 43.67 & 68.45 & 136.65 & 201.34 & 3.11 & 4.57 & 6.75 & 6.93 & 3.46 & 2.08 \\
\hline \multirow[t]{2}{*}{ LSD at $5 \%$} & 3.53 & 10.58 & 12.93 & 16.94 & 0.43 & 3.35 & 0.34 & 0.90 & 0.68 & 0.19 \\
\hline & \multicolumn{10}{|c|}{2016 season } \\
\hline Control & 31.45 & 49.00 & 65.18 & 106.89 & 5.78 & 6.54 & 5.99 & 8.70 & 2.18 & 1.60 \\
\hline $0.25+0.15+1.50$ & 43.48 & 86.12 & 86.64 & 191.01 & 8.21 & 8.67 & 7.15 & 9.99 & 2.43 & 1.91 \\
\hline $0.50+0.30+3.00$ & 68.01 & 164.90 & 130.24 & 391.58 & 9.72 & 11.65 & 9.80 & 10.83 & 2.93 & 2.56 \\
\hline LSD at $5 \%$ & NS & 25.55 & 47.92 & 19.27 & 3.44 & 3.77 & 2.86 & 1.70 & 0.09 & 0.37 \\
\hline
\end{tabular}


compared to control in both cuts in the two seasons, in most cases. Das et al. (2005) on stevia plant reported similar results as affected by zinc application. According to Kapoor et al. (2017), iron acts as an important catalyst in many enzymatic reactions of metabolism and helps in biosynthesis of photo assimilates thereby enhancing plant growth. Besides the function of iron in the metabolism of chloroplast RNA, it is required at several steps in the biosynthetic pathways leading to increase in the biosynthesis materials. In addition, zinc is a component of carbonic anhydrase, as well as several dehydrogenases and important for auxin production which in turn enhance plant growth and yield components.

\section{Effect of lithovit}

Results in Table 7 show that, in most cases, there was an increase in dry yields of stevia leaves and herb per faddan with increasing the tested lithovit rate during the two seasons in the two cuts. However, there was no significant differences between all rates of lithovit except treatment of $6 \mathrm{~g} / \mathrm{l}$, which gave significant increases compared to control. The results are in conformity with the findings of Farouk (2015) on Solanum tuberosum. Hamoda et al. (2016), on cotton plant, detected significant distinctions amongst four rates of $\mathrm{CO}_{2}$ nano fertilizer (in the form of Lithovit). Spraying plants with the high rate of $7.5 \mathrm{~g}$ lithovit/1 increased number of open bolls/plant, boll weight, seed yield/plant and seed yield/faddan followed by the medium rate $(5 \mathrm{~g} / 1)$, the low rate $(2.5 \mathrm{~g} / 1)$ and untreated plants (without lithovit).

\section{Effect of the Interaction Between Micronutrients and Lithovit}

Recorded results in Table 8 indicate that, in most cases, under the two tested micronutrient levels $(\mathrm{Fe}+\mathrm{Zn}+\mathrm{Mo}$ and $\mathrm{Fe}+\mathrm{Zn}+\mathrm{Mo}$ at 0.25 $+0.15+1.5$ and $0.50+0.30+3.0 \mathrm{~g} / \mathrm{l})$ different rates of lithovit gave significant increases in dry yields of leaves and herb per faddan compared to control in the two cuts during both seasons. Moreover, interaction of $(\mathrm{Fe}+\mathrm{Zn}+\mathrm{Mo}$ at $0.50+0.30+3.0 \mathrm{~g} / 1)$ with 4 or $6 \mathrm{~g} / 1$ lithovit gave the highest values with no significant between them, in most cases.

However, lithovit acts as an excellent fertilizer. The mechanism of this action is still not totally clear. Very probably, it is due to supplying the plants with carbon dioxide $\left(\mathrm{CO}_{2}\right)$ in much higher concentration than that in the atmosphere and so enabling the photosynthesis to take place with higher degree leading to a stronger natural growth and increasing yield. Furthermore, the supplements of micro-nutrients increasing the enzymatic activity should play also role in this process (Ghatas and Mohamed, 2018).

\section{Chemical Constituents and Active Ingredients}

\section{Effect of micronutrients}

Results in Table 6 show that percentages of reducing and none reducing sugars as well as total chlorophyll content $(\mathrm{mg} / \mathrm{g})$ in stevia leaves were increased by increasing micronutrients level. Likewise, the two micronutrients levels gave significant increases in this respect compared to control in both cuts during the two seasons. Also, the highest values in this concern were obtained from the micronutrients level of $(\mathrm{Fe}+\mathrm{Zn}+\mathrm{Mo}$ at $0.50+0.30+3.0 \mathrm{~g} / \mathrm{l})$ compared to control in the two seasons. These resulted are in harmony with those reported by Nasiri et al. (2010) on chamomile plant and Khater and Abd-Allah (2017) on sweet basil plants. Also, total chlorophyll content $(\mathrm{a}+\mathrm{b})$ in stevia leaves was increased by increasing micronutrients levels in both seasons, in most cases, compared to control. Amini et al. (2018) on Hyssopus officinalis plant found similar results.

\section{Effect of lithovit}

The obtained results in Table 7 demonstrate that increasing rates of lithovit gradually increased percentages of reducing and none reducing sugars as well as total chlorophyll content in stevia leaves. Moreover, all treatments gave high significant differences compared to control, in most cases. Furthermore, the highest rate of lithovit $(6 \mathrm{~g} / \mathrm{l})$ recorded the highest values in this connection. In addition, there were no significant difference between the treatments of 4 or $6 \mathrm{~g} / 1$ lithovit, in most cases. These results are in accordance with those reported by Dragicevic et al. (2016) on soybean plants.

Effect of the interaction between micronutrients and lithovit

Recorded results in Table 9 reveal that, in general, the interaction between lithovit and 
Table 7. Effect of foliar spray with lithovit on yield components and some chemical constituents of Stevia rebaudiana in the two cuts during the two seasons of 2015 and 2016

\begin{tabular}{|c|c|c|c|c|c|c|c|c|c|c|}
\hline \multirow{3}{*}{$\begin{array}{c}\text { Lithovit rate } \\
\text { (g/l) }\end{array}$} & \multicolumn{4}{|c|}{ Yield components } & \multicolumn{6}{|c|}{ Chemical constituents } \\
\hline & \multicolumn{2}{|c|}{$\begin{array}{l}\text { Dry leaves yield } \\
\text { /fad. (kg) }\end{array}$} & \multicolumn{2}{|c|}{$\begin{array}{c}\text { Dry herb yield /fad. } \\
\text { (kg) }\end{array}$} & \multicolumn{2}{|c|}{$\begin{array}{l}\text { Reducing } \\
\text { sugar (\%) }\end{array}$} & \multicolumn{2}{|c|}{$\begin{array}{l}\text { Non-reducing } \\
\text { sugar }(\%)\end{array}$} & \multicolumn{2}{|c|}{$\begin{array}{c}\text { Total chlorophyll } \\
\text { content (mg/g) }\end{array}$} \\
\hline & $1^{\text {st }}$ cut & $2^{\text {nd }}$ cut & $1^{\text {st }}$ cut & $2^{\text {nd }}$ cut & $1^{\text {st }}$ cut & $2^{\text {nd }}$ cut & $1^{\text {st }}$ cut & $2^{\text {nd }}$ cut & $1^{\text {st }}$ cut & $2^{\text {nd }} \mathrm{cut}$ \\
\hline & \multicolumn{10}{|c|}{2015 season } \\
\hline Control & 34.37 & 58.08 & 98.57 & 160.90 & 1.27 & 1.67 & 4.68 & 3.66 & 2.61 & 1.63 \\
\hline 2 & 35.71 & 58.08 & 104.33 & 167.27 & 1.74 & 2.05 & 4.84 & 4.73 & 2.85 & 1.71 \\
\hline 4 & 39.37 & 61.04 & 117.62 & 172.90 & 1.96 & 2.33 & 5.39 & 4.97 & 3.02 & 1.83 \\
\hline 6 & 40.02 & 62.23 & 120.27 & 181.05 & 2.11 & 3.84 & 5.85 & 5.56 & 3.04 & 1.89 \\
\hline \multirow[t]{2}{*}{ LSD at $5 \%$} & 5.09 & NS & 17.38 & 11.34 & 0.40 & NS & 0.65 & 0.99 & 0.33 & 0.13 \\
\hline & \multicolumn{10}{|c|}{2016 season } \\
\hline Control & 39.48 & 88.45 & 78.51 & 193.79 & 7.01 & 8.21 & 7.09 & 9.01 & 2.33 & 1.80 \\
\hline 2 & 45.90 & 98.82 & 91.38 & 222.97 & 7.83 & 8.52 & 7.25 & 9.79 & 2.41 & 1.87 \\
\hline 4 & 48.06 & 104.01 & 97.48 & 234.68 & 8.12 & 9.17 & 7.58 & 10.16 & 2.57 & 2.14 \\
\hline 6 & 57.14 & 108.75 & 108.70 & 267.87 & 8.65 & 9.92 & 8.66 & 10.40 & 2.73 & 2.28 \\
\hline LSD at $5 \%$ & NS & 41.72 & NS & 64.84 & 1.53 & NS & NS & NS & 0.14 & 0.33 \\
\hline
\end{tabular}

Table 8. Effect of the interaction between micronutrients and lithovit on yield components of Stevia rebaudiana plant during 2015 and 2016 seasons

\begin{tabular}{lcccccccc}
\hline $\begin{array}{c}\text { Micronutrient } \\
\text { level (g/l) }\end{array}$ & \multicolumn{7}{c}{ Lithovit rate (g/l) } \\
\cline { 2 - 8 }$(\mathbf{F e}+\mathbf{Z n + M o})$
\end{tabular}


Table 9. Effect of the interaction between micronutrients and lithovit on reducing and nonreducing sugars and total chlorophyll content in leaves of Stevia rebaudiana plant during 2015 and 2016 seasons

\begin{tabular}{|c|c|c|c|c|c|c|c|c|}
\hline \multirow{3}{*}{$\begin{array}{c}\text { Micronutrient } \\
\text { level (g/l) } \\
(\mathrm{Fe}+\mathrm{Zn}+\mathrm{Mo}) \\
\end{array}$} & \multicolumn{8}{|c|}{ Lithovit rate $(\mathrm{g} / \mathrm{l})$} \\
\hline & Control & 2 & 4 & 6 & Control & 2 & 4 & 6 \\
\hline & \multicolumn{4}{|c|}{ First cut } & \multicolumn{4}{|c|}{ Second cut } \\
\hline & \multicolumn{8}{|c|}{ Reducing sugar (\%) } \\
\hline & \multicolumn{8}{|c|}{2015 season } \\
\hline Control & 0.49 & 0.96 & 1.05 & 1.10 & 0.61 & 0.95 & 1.06 & 1.30 \\
\hline $0.25+0.15+1.50$ & 1.12 & 1.29 & 1.29 & 1.48 & 1.51 & 1.65 & 1.93 & 2.38 \\
\hline $0.50+0.30+3.00$ & 2.19 & 2.96 & 3.54 & 3.76 & 2.90 & 3.54 & 3.99 & 7.84 \\
\hline \multirow[t]{2}{*}{ LSD at $5 \%$} & \multicolumn{4}{|c|}{0.73} & \multicolumn{4}{|c|}{ NS } \\
\hline & \multicolumn{8}{|c|}{2016 season } \\
\hline Control & 4.52 & 5.56 & 5.98 & 7.05 & 5.98 & 6.10 & 6.52 & 7.57 \\
\hline $0.25+0.15+1.50$ & 7.69 & 8.16 & 8.45 & 8.55 & 7.68 & 8.28 & 8.92 & 9.78 \\
\hline $0.50+0.30+3.00$ & 8.83 & 9.76 & 9.92 & 10.36 & 10.97 & 11.18 & 12.06 & 12.40 \\
\hline \multirow[t]{3}{*}{ LSD at $5 \%$} & \multicolumn{4}{|c|}{4.10} & \multicolumn{4}{|c|}{7.67} \\
\hline & \multicolumn{8}{|c|}{ Non-reducing sugar (\%) } \\
\hline & \multicolumn{8}{|c|}{2015 season } \\
\hline Control & 3.25 & 3.34 & 3.97 & 4.54 & 1.92 & 2.79 & 3.25 & 3.56 \\
\hline $0.25+0.15+1.50$ & 4.80 & 4.98 & 5.09 & 5.36 & 3.68 & 4.28 & 4.30 & 5.26 \\
\hline $0.50+0.30+3.00$ & 6.00 & 6.21 & 7.12 & 7.66 & 5.37 & 7.13 & 7.36 & 7.87 \\
\hline \multirow[t]{2}{*}{ LSD at 5\% } & \multicolumn{4}{|c|}{1.03} & \multicolumn{4}{|c|}{1.73} \\
\hline & \multicolumn{8}{|c|}{2016 season } \\
\hline Control & 5.58 & 5.85 & 6.01 & 6.53 & 6.69 & 8.77 & 9.66 & 9.69 \\
\hline $0.25+0.15+1.50$ & 6.72 & 6.88 & 6.99 & 8.01 & 9.80 & 9.80 & 9.85 & 10.51 \\
\hline $0.50+0.30+3.00$ & 8.98 & 9.01 & 9.74 & 11.45 & 10.54 & 10.80 & 10.98 & 11.01 \\
\hline \multirow[t]{3}{*}{ LSD at $5 \%$} & \multicolumn{4}{|c|}{3.90} & \multicolumn{4}{|c|}{2.65} \\
\hline & \multicolumn{8}{|c|}{ Total chlorophyll content $(\mathrm{mg} / \mathrm{g})$} \\
\hline & \multicolumn{8}{|c|}{2015 season } \\
\hline Control & 2.00 & 2.46 & 2.33 & 2.39 & 1.33 & 1.45 & 1.60 & 1.62 \\
\hline $0.25+0.15+1.50$ & 2.61 & 2.72 & 3.16 & 3.03 & 1.66 & 1.73 & 1.71 & 1.77 \\
\hline $0.50+0.30+3.00$ & 3.22 & 3.37 & 3.56 & 3.71 & 1.91 & 1.96 & 2.18 & 2.28 \\
\hline \multirow[t]{2}{*}{ LSD at $5 \%$} & \multicolumn{4}{|c|}{0.83} & \multicolumn{4}{|c|}{0.27} \\
\hline & & & & 2016 & ason & & & \\
\hline Control & 2.02 & 2.14 & 2.26 & 2.29 & 1.49 & 1.57 & 1.65 & 1.69 \\
\hline $0.25+0.15+1.50$ & 2.35 & 2.40 & 2.42 & 2.55 & 1.75 & 1.79 & 2.05 & 2.05 \\
\hline $0.50+0.30+3.00$ & 2.65 & 2.68 & 3.04 & 3.36 & 2.14 & 2.26 & 2.73 & 3.11 \\
\hline LSD at $5 \%$ & & & & & & & & \\
\hline
\end{tabular}


microelements increased reducing and none reducing sugars percentages and chlorophyll $(\mathrm{a}+\mathrm{b})$ content in stevia leaf tissues as compared with the control. Increased the interacted lithovit rate from 2, 4, $6 \mathrm{~g} / \mathrm{l}$ resulted in significant increases in abovementioned characteristics under different levels of microelements. In addition, the highest values in this regard were recorded under the effect of interaction treatments between micronutrient level of $(\mathrm{Fe}+\mathrm{Zn}+\mathrm{Mo}$ at $0.50+0.30+3.0 \mathrm{~g} / \mathrm{l})$ and lithovit at 4 or $6 \mathrm{~g} / 1$ in first and second seasons, with significant increase compared to control.

\section{Stevioside and rebaudioside determinations}

Results represented effect of foliar spray of $(\mathrm{Fe}+\mathrm{Zn}+\mathrm{Mo})$ elements, lithovit and their interactions on leaf tissue contents of stevioside and rebaudioside are recorded in Table 10. It is clear that spraying stevia plants with the highest tested level of micronutrients $(\mathrm{Fe}+\mathrm{Zn}+\mathrm{Mo}$ at $0.50+0.30+3.00 \mathrm{~g} / 1$, respectively) or of lithovit
(6 g/l), each alone resulted in increases in stevioside and rebaudioside contents in leaves comparing to unsprayed control plants. In addition, more increases in stevioside and rebaudioside contents were resulted under the effect of interaction treatment between the abovementioned two highest levels of micronutrients and lithovit. This was true in the two cuts during both experimental seasons. However, these treatments increased plant growth, leaves and herb yields as well as the determined chemical constituents as mentioned above in this research (Tables 2-9).

\section{Conclusion}

From abovementioned results, it is preferable to spray Stevia rebaudiana plants with lithovit at $4 \mathrm{~g} / \mathrm{l}$ plus $(\mathrm{Fe}+\mathrm{Zn}+\mathrm{Mo}$ at $0.50+0.30+3.00 \mathrm{~g} / \mathrm{l}$, respectively) three times per season to enhance the growth, yield and chemical constituents as well as active ingredients of this important medicinal plant.

Table 10. Effect of foliar spray with micronutrients, lithovit and their interactions on stevioside and rebaudioside percentages in leaf tissues of Stevia rebaudiana during 2015 and 2016 seasons

\begin{tabular}{|c|c|c|c|c|c|c|c|c|}
\hline \multirow[t]{3}{*}{ The treatment } & \multicolumn{4}{|c|}{ Stevioside } & \multicolumn{4}{|c|}{ Rebaudioside } \\
\hline & \multicolumn{2}{|c|}{$1^{\text {st }}$ season } & \multicolumn{2}{|c|}{$2^{\text {nd }}$ season } & \multicolumn{2}{|c|}{$1^{\text {st }}$ season } & \multicolumn{2}{|c|}{$2^{\text {nd }}$ season } \\
\hline & $\overline{1^{\text {st }} \text { cut }}$ & $2^{\text {nd }}$ cut & $\overline{1^{\text {st }} \text { cut }}$ & $2^{\text {nd }}$ cut & $\overline{1^{\text {st }} \text { cut }}$ & $2^{\text {nd }}$ cut & $\overline{1^{\text {st }} \text { cut }}$ & $2^{\text {nd }}$ cut \\
\hline Control & 1.77 & 1.74 & 3.99 & 4.35 & 1.88 & 2.08 & 1.73 & 2.58 \\
\hline Micronutrients ${ }^{@}$ & 2.40 & 2.01 & 6.02 & 4.62 & 2.18 & 2.09 & 4.96 & 4.01 \\
\hline Lithovit at $6 \mathrm{~g} / \mathrm{l}$ & 2.18 & 2.20 & 6.16 & 5.88 & 2.56 & 3.75 & 3.27 & 3.75 \\
\hline Lithovit at $6 \mathrm{~g} / \mathrm{l}+$ Micronutrients & 2.35 & 5.99 & 6.39 & 8.33 & 2.80 & 5.25 & 5.40 & 3.85 \\
\hline
\end{tabular}

\footnotetext{
${ }^{\infty}$ Foliar spray of $\mathrm{Fe}+\mathrm{Zn}+\mathrm{Mo}$ at $0.50+0.30+3 \mathrm{~g} / \mathrm{l}$, respectively.
} 


\section{REFERENCES}

Amini, I.M., S. Yousefzadeh and K. SadatAsilan (2018). A study on variations of essential oil yield and composition of Hyssopus officinalis L. affected by foliar application of zinc, iron and manganese. Iranian J. Med. and Aromatic Pl., 34 (1):131143.

Analytical Software (2008). Statistix Version 9, Analytical Software, Tallahassee, Florida, USA.

Aranda-González, I., Y. Moguel-Ordoñez and D. Betancur-Ancona (2015). Determination of rebaudioside and stevioside in leaves of stevia rebaudiana bertoni grown in méxico by a validated HPLC method. Ame. J. Anal. Chem., 6: 878-885.

Baloch, Q.B., Q.I. Chachar and M.N. Tareen (2008). Effect of foliar application of macro and micro nutrients on production of reen chilies (Capsicum annuum L.). J. Agric. Tech., 4 (2): 177-184.

Bernal, M., R. Cases, R. Picorel and I. Yruela (2007). Foliar and root $\mathrm{Cu}$ supply affect differently $\mathrm{Fe}$ and Zn-uptake and photosynthetic activity in soybean plants. Environ. Exp. Botany, 60: 145-150.

Carbonell, M.V., M. Florez, M.E. Martinez, R. Maqueda and J.M. Amaya (2011). Study of stationary magnetic fields on initial growth of pea (Pisum sativum L.) seeds. Seed Sci. and Technol., 39 (3): 673-679.

Carmen, B., R. Sumalan, S. Gadea and S. Vatca (2014). Physiological indicators study involved in productivity increasing in tomato. Pro-Environ., 7: 218 - 224.

Chapman, H. and P. Pratt (1978). Methods of Analysis for Soils, Plants and Waters. Div. Agric., Sci. Univ. Calif. USA, 16-38.

Curi, R., M. Alvarex and R.B. Bazotte (1986). Effect of Stevia rebaudiana on glucose tolerance in normal adult humans. Brazilian J. Med. and Biol. Res., 19: 771-774.

Das, K., R. Dang, T.N. Shivananda and P. Sur (2005). Interaction between phosphorus and zinc on the biomass yield and yield attributes of the medicinal plant stevia (Stevia rebaudiana). Sci. World J., 5: 390-395.

Dragicevic, V., B. Nikolic, H. Waisi, M. Stojiljkovic and M. Simic (2016). Increase of soybean nutritional quality with nonstandard foliar fertilizers. J. Cent. Europ. Agric., 17 (2): 356-368.

Esitken, A. and M. Turan (2004). Alternating magnetic field effects on yield and plant nutrient elementcomposition of strawberry (Fragaria X Ananassa cv. camarosa). Acta Agriculturae Scandinavica, Section B- Plant Soil Sci., 54 (3): 135-139.

Farouk, S. (2015). Improving growth and productivity of potato (Solanum tuberosum L.) by some biostimulants and lithovit with or without boron. J. Pl. Prod., Mansoura Univ., 6 (12): 2187 - 2206.

Ghatas, Y.A.A. and Y.F.Y. Mohamed (2018). Influence of mineral, micro-nutrients and lithovit on growth, oil productivity and volatile oil constituents of Cymbopogon citruts L. plants. Middle East J. Agric. Res., 7 (1): 162-174.

Hall, J. L. and L.E. Williams (2003). Transition metal transporters in plants. J. Exp. Bot., 54 (393): 2601-2613.

Hamoda, S.A.F., A.N.E. Attia, M.H. El-Hendi and S.O.S. El-Sayed (2016). Effect of nanofertilizer (lithovit) and potassium on growth, fruiting and yield of Egyptian cotton under different planting dates. Int. J. Adv. Res. Biol. Sci., 3 (12): 29-49.

Kapoor, A.C., B. Mukesh and R.R. Sen (2017). Effectiveness of micronutrients in the improvement of seed yield and quality of coriander cv.CO4. Adv. Seed Sci. and Technol., 1 (6): 37-41.

Kaya, M., M. Atak, K.K. Mahmood, C.Y. Çiftçi, and S. Özcan (2005). Effect of pre-sowing seed treatment with zinc and foliar spray of humic acids on yield of common bean (Phaseolus vulgaris L.). Int. J. Agri. Biol., 6 (7): 875-878.

Khater, R.M. and W.H.A. Abd-Allah (2017). Effect of some trace elements on growth, yield and chemical constituents of Ocimum 
basilicum plants. Egypt. J. Desert Res., 67 (1): $1-23$.

Li, S.X., Z.H. Wang and B.A. Stewart (2013). Responses of crop plants to ammonium and nitrate N. Adv. Agron., 118: 205-397.

Lyakhovkin, A.G., T.D. Long, D.A. Titov and M.P. Anh (1993). Cultivation and Utilization of Stevia (Stevia rebaudiana Bertoni) (pp. 1-44). Hanoi: Agric. Publishing House.

Marschner, H. (1995). Mineral Nutrition of Higher Plants. $2^{\text {nd }}$ Ed. New York: Acad., 889.

Mazumder, B.C. and K. Majumder (2003). Methods of Physiochemical Analysis of Fruits. Daya Publishing House Delhi, India.

Mengel, K. and E.A. Kirkby (2001). Principles of Plant Nutrition. $5^{\text {th }}$ Ed. Academic Publishers, Dordrecht, Kluwer, USA.

Nasiri, Y., S. Zehtab-Salmasi, S. Nasrullahzadeh, N. Najafi and K. Ghassemi-Golezani (2010).
Effects of foliar application of micronutrients ( $\mathrm{Fe}$ and $\mathrm{Zn}$ ) on flower yield and essential oil of chamomile (Matricaria chamomilla L.). J. Med. Pl. Res., 17 (4): 1733-1737.

Said-Al-Ahl, H.A.H. and A. Mahmoud (2010). Effect of zinc and/or iron foliar application on growth and essential oil of sweet basil (Ocimum basilicum L.) under salt stress. Ozean J. Appl. Sci., 3: 97-111.

Zehtab-Salmasi, S., F. Heidari and H. Alyari (2008). Effects of microelements and plant density on biomass and essential oil production of peppermint (Mentha piperita L.). Pl. Sci. Res., 1: 24-26.

Ziedan, E.H. and E.A. Eisa (2016). The use of some micronutrients and plant extracts of resistance to powdery mildew and nutrition dill plants in the Gharbiyah Governorate. J. Plant Prot. and Path., Mansoura Univ., 7 (9): $579-586$.

\section{تأثير الرش الورقي بالحديد والزنك والموليبنيم والليثوفيت على نمو وإنتاجية نبات الإستيفيا \\ أماني محمد اسماعيل سليمان - عبد الرحمن العريان عوض أرض \\ أحمد شاكر حسين جندي ـ محمد أحمد إبراهيم عبد القادر

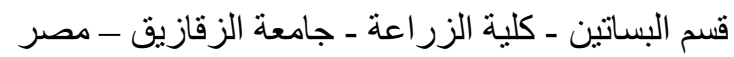

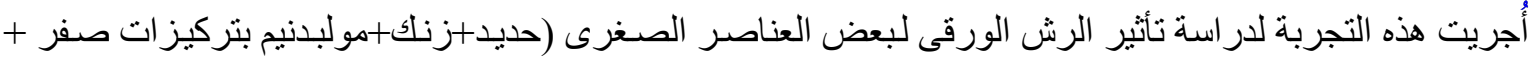

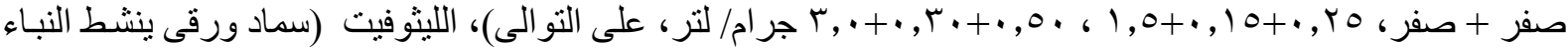

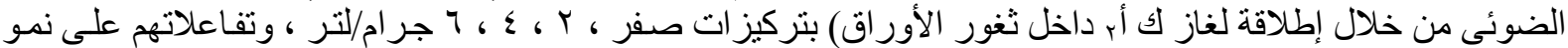

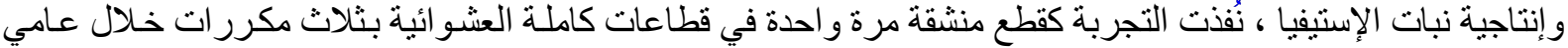

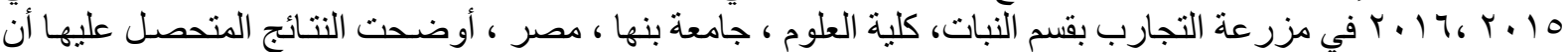

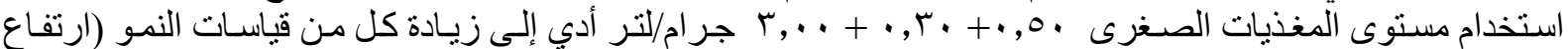

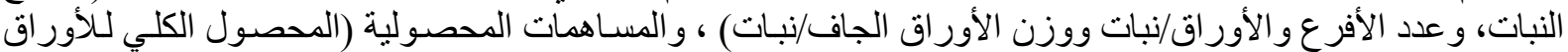

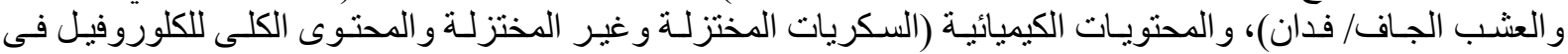

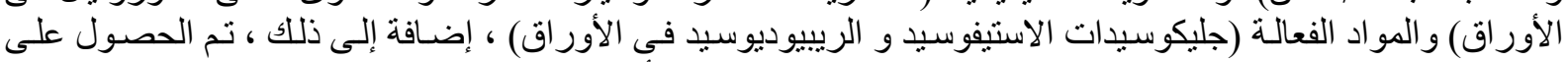

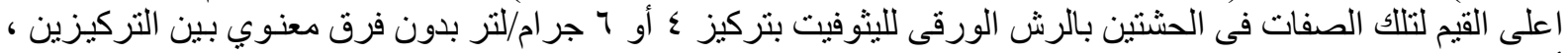

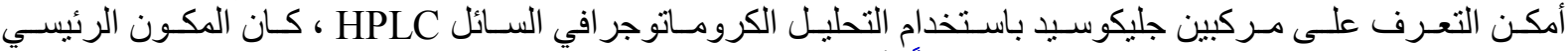

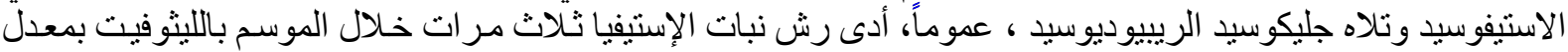

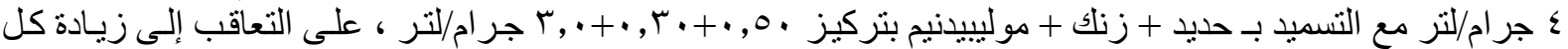
من النمو و المحصول وبعض التصو المحتويات الكيميائية و المو اد الفعالة.

أستاذ نباتات الزينة و الطبية و العطرية - كلبة الزر اعة - جامعة الأز هر بأسيوط.

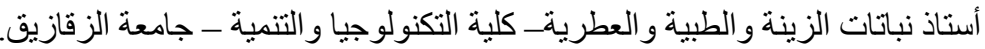

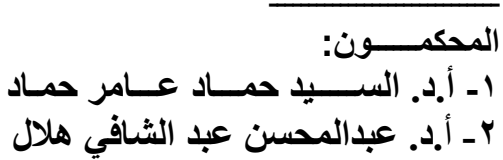

